\title{
FAKTOR YANG BERHUBUNGAN DENGAN PENGETAHUAN IBU HAMIL TENTANG ASAM FOLAT DALAM KEHAMILAN
}

\author{
Rina Doriana Pasaribu \\ Jurusan Kebidanan Poltekkes Kemenkes Medan; rinadoriana@gmail.com
}

\begin{abstract}
Abstrak
Latarbelakang. Asam folat merupakan salah satu zat gizi penting bagi kehamilan terutama pada 12 minggu pertama kehamilan. Sekitar 24-60\% ibu hamil di Negara berkembang maupun Negara maju mengalami kekurangan asam folat. Tujuan penelitian ini adalah untuk mengetahui faktor-faktor yang berhubungan dengan pengetahuan ibu hamil tentang konsumsi asam folat bagi kehamilan. Metodologi penelitian. Jenis penelitian yang digunakan adalah survey anaitik dengan desain cross sectional. Penelitian dilakukan di Desa Saentis Kecamatan Percut Sei Tuan Kabupaten Deli Serdang pada bulan Nopember 2014 - April 2015. Populasi pada penelitian ini adalah seluruh ibu hamil di Desa Saentis yaitu sebanyak 47 orang dan seluruh populasi dijadikan sebagai sampel. Hasil penelitian. Hasil uji statistik menunjukkan adanya hubungan umur terhadap pengetahuan ibu hamil tentang konsumsi asam folat ( $p<0,05, \mathrm{RP}=0,496,95 \%, \mathrm{Cl}: 0,291-0,843$ ), ada hubungan pendidikan terhadap pengetahuan ibu hamil tentang $\operatorname{konsumsi}$ asam folat $(p<0,05 ; \mathrm{RP}=$ $0,630,95 \%, \mathrm{Cl}: 0,383-1,037)$, ada hubungan sumber informasi dengan pengetahuan ibu hamil tentang konsumsi asam folat bagi kehamilan ( $\mathrm{p}<0,05 ; \mathrm{RP}=2,954,95 \%, \mathrm{Cl}: 1,324-6,588$ ). Saran. Peningkatan KIE bidan tentang pentingnya mengonsumsi asam folat pada ibu hamil.
\end{abstract}

Kata kunci : Pengetahuan, Ibu Hamil, Asam Folat

\section{PENDAHULUAN}

Asam folat merupakan salah satu vitamin dari kelompok vitamin B yang sangat penting bagi kehamilan khususnya pada 12 minggu pertama kehamilan. Ketika tubuh bayi sedang dibentuk guna untuk mencegah terjadinya kecacaan tabung saraf yang sedang berkembang. Kekurangan asam folat dapat menyebabkan kecacatan pada bayi yang di lahirkan seperti Neural Tube Defect (NTD) yaitu spina Bifida, Anensefali (Hunter, 2005). Asam folat merupakan satu-satunya vitamin yang kebutuhannya selama hamil dua kali lipat sebelum hamil. Sekitr 24-60\% wanita, baik di Negara sedang berkembang maupun di Negara maju mengalami kekurangan asam folat ( Arisman $2010)$.

Menurut World Health Organization (WHO), tubuh orang dewasa membutuhkan 400 mikrogram asam folat setiap harinya. Sedangkan pada wanita hamil asupan asam folat yang diperlukan sebanyak 800 mikrogram/hari. Sedangkan Menurut Angka Kecukupan Gizi Indonesia, Konsumsi asam folat yang dianjurkan adalah 400 mikrogram perhari. Pada wanita hamil atau wanita menjelang hamil, perlu ada tambahan 200 mikrogram perhari. Kejadian cacat bawaan fisik di Amerika Serikat (AS) 1,32 per 1.000 kelahiran salah satunya karena kekurangan asam folat. Angka kematian bayi (AKB) di Indonesia pada tahun 2007 adalah 34/1000 kelahiran hidup. Salah satunya karena kekurangan asam folat (Dyahumi, 2011).

Di Amerika, setiap tahunnya sekitar 4.000 kehamilan mengalami NTD. Dari jumlah tersebut, sekitar
2.500 bayi lahir dengan menderita NTD. Sedangkan di Indonesia memang belum ada data yang pasti mengenai jumlah penderita Neural Tube Defect. Namun setiap bulan, dari 300 ibu hamil yang memeriksakan kehamilannya di RSCM, 3 pasien diantaranya terbukti janinnya menderita NTD (Aprillia, 2011).

Angka kematian bayi (AKB) di indonesi pada tahun 2007 adalah 34/1000 kelahiran hidup sedangkan di Sumtara Utara adalah 46/1000 kelahiran hidup. Salah satu penyebab kematian bayi adalah karena kekurangan Asam folat. (Profil kesehatan Indonesia, 2010).

Angka kejadian anemia di Indonesia masih sangat tinggi. Dalam penelitian Dewa ayu Surinati, ia mengatkan bahwa angka kejadian anemia yang disebabkan karena kekurangan asam folat adalah sebesar $29 \%$.

Angka kejadian dan resiko untuk NTD beragam dari angka 7,5 sampai 11,6 per 10000 kelahiran hidup. Di Indonesia sendiri belum ada data pasti berapa besarnya prevalensi adanya penyakit kelainan sumsum tulang belakang. Angka turun dari 3,5\% sampai $1 \%$ pada wanita yang secara acak diberikan asam folat 400 mikrogram sebelum kehamilan dan selama 6 minggu pertama kehamilan.

Karena pentingnya zat yang satu ini, kebutuhan asam folat untuk ibu hamil harus disiapkan sejak sebelum hamil. Jika dimulai pada satu bulan sebelum kehamilan dan tiga bulan pertama kehamilan akan menurunkan beban resiko bayi lahir terhadap NTD lebih dari $70 \%$ (Admin,2009). 
Dari hasil survey awal bulan Mei di Klinik Bersalin Keliat dilakukan wawancara kepada 5 orang ibu hamil, ternyata hanya satu orang yang mengetahui tentang asam folat bagi kehamilan. Berdasarkan hasil wawancara, maka penulis tertarik untuk melakukan penelitian mengenai faktor-faktor yang berhubungan dengan pengetahuan ibu hamil tentang konsumsi asam folat bagi kehamilan di Klinik Bersalin Keliat tahun 2012.

\section{Rumusan Masalah}

Berdasarkan permasalahan diatas, penulis merumuskan masalah penelitian sebagai beriku : faktorfaktor apa sajakah yang berhubungan dengan pengetahuan ibu hamil tentang konsumsi asam folat bagi kehamilan di Klinik Bersalin Keliat.

\section{Tujuan Penelitian}

Tujuan Umum

Penelitian ini bertujuan untuk mengetahuhi "Faktor-faktor Yang Berhubungan Dengan Pengetahuan Ibu Hamil Tentang Konsumsi Asam Folat Bagi Kehamilan di Klinik Bersalin Keliat.

\section{Tujuan Khusus}

1. Untuk mengetahui distribusi pengetahuan ibu hamil tentang konsumsi asam folat.

2. Untuk mengetahui hubungan umur dengan pengetahuan ibu hamil tentang konsumsi asam folat bagi kehamilan

3. Untuk mengetahui hubungan pendidikan dengan pengetahuan ibu hamil tentang Konsumsi asam folat bagi kehamilan

4. Untuk mengetahuai hubungan sumber informasi dengan pengetahuan ibu hamil tentang konsumsi asam folat bagi kehamilan

\section{Hipotesis Penelitian}

Hipotesis dalam penelitian ini adalah umur, tingkat pendidikan dan sumber informasi berhubungan dengan pengetuan ibu hamil tentang asam folat dalam kehamilan.

\section{Metode Penelitian \\ Jenis penelitian}

Penelitian ini adalah survey analitik dengan menggunakan data primer yang diperoleh langsung dari responden untuk untuk mengetahui faktor-faktor yang berhubungan dengan pengetahuan ibu hamil tentang konsumsi asam folat bagi kehamilan di Klinik Bersalin Keliat.

\section{Lokasi dan Waktu Penelitian}

Penelitian ini dilaksanakan di Klinik Bersalin Keliat pada bulan Nopember 2014 - April 2015 yang dimulai dengan penulisan proposal, pengumpulan data dan pembuatan laporan penelitian.

\section{Populasi dan sampel}

Populasi dalam penelitian ini adalah seluruh ibu hamil yang datang memeriksakan kehamilannya ke Klinik
Bersalin Keliat pada bulan Desember 2014 sampai dengan Maret 2015 sebanyak 94 orang. Tehnik sampling yang digunakan adalah teknik accidental sampling.

\section{Metode Pengumpulan Data}

Penelitian ini menggunakan data primer yang diperoleh langsung dari responden, dengan alat bantu kuesioner. Kuesioner diberikan dengan bentuk wawancara terpimpin (peneliti yang membacakan pertanyaan). Pengumpulan data dilakukan mulai dari Desember 2014 sampai dengan Maret 2015.

\section{Analisa Data}

1. Analisa data Univariat

Analisa data Univariat ini digunakan untuk mendapatkan distribusi frekuensi atau besarnya proporsi dari variabel independen dan variabel dependen sehingga dapat diketahuai variasi dari masing-masing variabel.

\section{Analisa data Bivariat}

Analisa data Bivariat digunakan untuk melihat hubungan umur, tingkat pendidikan dan sumber informasi dengan pengetahuan ibu hamil tentang asam folat dalam kehamilan.

\section{HASIL DAN PEMBAHASAN}

Hasil Penelitian

Analisa Data Univariat

Tabel 1. Distribusi Frekuensi Ibu Hamil Tentang Konsumsi Asam Folat Di Klinik Bersalin Keliat

\begin{tabular}{|c|c|c|c|}
\hline No & Variabel & $\mathrm{n}$ & $\%$ \\
\hline \multirow[t]{3}{*}{1.} & Pengetahuan ibu & & \\
\hline & a. Baik & 36 & 38,3 \\
\hline & b. Kurang & 58 & 61,7 \\
\hline \multirow[t]{3}{*}{2.} & Umur ibu & & \\
\hline & a. $<30$ tahun & 68 & 72,3 \\
\hline & b. $\geq 30$ tahun & 26 & 27,7 \\
\hline \multirow[t]{3}{*}{3.} & Pendidikan ibu & & \\
\hline & a. Mengah kebawah & 64 & 68,1 \\
\hline & b. Menegah keatas & 30 & 31,9 \\
\hline \multirow[t]{4}{*}{4.} & Sumber informasi & & \\
\hline & a. Mendapat informasi & 34 & 36,2 \\
\hline & $\begin{array}{l}\text { b. Tidak mendapat } \\
\text { Informasi }\end{array}$ & 60 & 63,8 \\
\hline & Jumlah & 94 & \\
\hline
\end{tabular}

\section{Analisa Data Bivariat}

Analisa data bivariat digunakan untuk melihat kemaknaan hubungan antara variable independen dan variable dependen yang dilakukan uji statistik Chi-Square $\left(X^{2}\right)$. 
Tabel 2. Analisis Hubungan Umur, Tingkat Pendidikan dan Sumber informasi dengan Pengetahuan Ibu Hamil Tentang konsumsi Asam Folat di Klinik Bersalin Keliat

\begin{tabular}{lccccccccc}
\hline \multicolumn{1}{c}{ Kengetahuan Ibu } & Jumlah & & & \\
Kategori & Baik & \multicolumn{1}{c}{ Kurang } & & & & RP & Cl \\
& $\mathrm{N}$ & $\%$ & $\mathrm{~N}$ & $\%$ & $\mathrm{~N}$ & $\%$ & & & \\
\hline Umur & 16 & 23,5 & 52 & 76,5 & 68 & 100 & & & \\
$<30$ & 20 & 76,9 & 6 & 23,1 & 26 & 100 & 0,001 & 0,496 & $0,291-$ \\
$\geq 30$ & & & & & & & & &
\end{tabular}

Tingkat Pendidikan

$\begin{array}{lllllll}\text { Menengah } & 18 & 28,1 & 46 & 79,9 & 64 & 100\end{array}$

kebawah

$\begin{array}{llllllllll}\text { Menengah } & 18 & 60,0 & 12 & 40,0 & 30 & 100 & 0,039 & 0,630 & 0,383-\end{array}$

keatas

Sumber Informasi

Mendapatkan $22 \quad 64,7 \quad 12 \quad 35,3 \quad 34 \quad 100$

Informasi

$\begin{array}{llllllllll}\text { Tidak } & 14 & 23,3 & 46 & 76,7 & 60 & 100 & 0,006 & 2,495 & 1,324-\end{array}$

Mendapatkan

informasi

\begin{tabular}{lllllll} 
Jumlah & 36 & 38,3 & 58 & 61,7 & 94 & 100 \\
\hline
\end{tabular}

\section{Pembahasan}

1. Diatribusi Frekuensi Ibu Hamil Tentang Konsumsi Asam Folat Di Klinik Bersalin Keliat Tahun 2012

Dari tabel 1 dapat diketahui bahwa jumlah ibu hamil yang memiliki pengetahuan kurang sebanyak 58 orang $(61,7 \%)$ dari 94 jumlah seluruh responden, sedangkan yang paling sedikit adalah ibu yang memiliki pengetahuan baik yaitu 36 orang $(38,3 \%)$. Dari hasil penelitian ini dapat disimpulkan bahwa ibu yang menjadi responden di Klinik Bersalin Keliat mayoritas ibu yang memiliki pengetahuan kurang.

Berdasarkan umur, responden yang paling banyak adalah ibu yang memiliki umur $<30$ tahun yaitu 68 orang $(72,3 \%)$ dari 94 jumlah sluruh responden, sedangkan yang paling sedikit adalah ibu yang mmiliki umur $\geq 30$ tahun yaitu 26 orang $(27,7 \%)$. Dari hasil penelitian ini dapat disimpulkan bahwa ibu yang menjadi responden di Klinik Bersalin Keliat mayoritas ibu yang memiliki umur < 30 tahun.

Berdasarkan pendidikan ibu, responden yang paling banyak adalah ibu yang memiliki pendidikan menengah kebawah (SMP,SD dan Tidak sekolah) yaitu 64 orang $(68,1 \%)$ dari 94 jumlah seluruh responden, sedangkan yang paling sedikit adalah ibu yang memiliki pendidikan menengah keatas (SMA dan perguruan tinggi) yaitu 30 orang $(31,9 \%)$. Dari hasil penelitian ini dapat disimpulkan bahwa ibu yang menjadi responden di Klinik Bersalin Keliat Mayoritas ibu yang memilki pendidikan menengah kebawah.

Berdasarkan sumber informasi, responden yang paling banyak adalah ibu yang tidak mendapat informasi yaitu 60 orang $(63,8 \%)$ dari 94 orang jumlah seluruh responden, sedangkan yang paling sedikit adalah ibu yang mendapatkan informasi yaitu 34 orang $(36,2 \%)$. Dari hasil penelitian ini dapat disimpulkan bahwa ibu yang menjadi responden di Klinik Brsalin Keliat mayoritas ibu yang tidak mendapatkan informasi.

\section{Hubungan Umur Terhadap Pengetahuan Ibu Hamil Tentang Konsumsi Asam Folat di Klinik Bersalin Keliat}

Umur merupakan salah satu faktor yang mempengaruhi pengetahuan ibu. Berdasarkan hasil penelitian bahwa dari 58 orang ibu hamil yang berpengetahuan kurang, ibu yang berpengetahuan kurang paling banyak adalah ibu dengan umur $<30$ tahun dengan jumlah 52 orang $(77,5 \%)$, sedangkan yang paling sedikit adalah ibu dengan umur $\geq 30$ tahun berjumlah 12 orang $(23,1 \%)$.

Hasil uji Chi - Square $\left(\mathrm{X}^{2}\right)$ diperoleh nilai $p<$ $0,05, \mathrm{RP}=0,496(95 \%, \mathrm{Cl}: 0,291-0,843)$ yang artinya ibu hamil yang berumur $<30$ tahun memiliki pengetahuan kurang 0,496 kali dibandingkan dengan ibu hamil yang memiliki umur $\geq 30$ tahun. Sedangkan nilai $p$ value (< 0,05) maka disimpulkan bahwa terdapat hubungan yang bermakna antara umur denngan pengetahuan ibu hamil tentang konsumsi asam folat.

Hal tersebut sesuai dengan teori yang dikemukakan oleh Notoatmodjo (2007), yaitu umur sangat erat hubungannya dengan tingkat pengetahuan seseorang karena semakin bertambahnya usia manusia maka semakin banyak pula pengetahuan yang didapatkannya terutama dalam hal pengetahuan ibu hamil tentang asam folat.

Semakin tua umur seseorang maka tingkat pengetahuan akan semakin baik. Hal ini sesuai dengan penelitian Prasetyo (2011) yang menyatakan bahwa pengetahuan ibu yang baik tentang konsumsi asam folat paling banyak pada usia 26 - 30 tahun, sedangkan yang memiliki pengetahuan kurang paling banyak pada usia < 21 tahun.

Umur mempengaruhi daya tangkap dan pola pikir seseorang. Semakin bertambah umur akan semakin berkembang pula daya tangkap dan pola pikirnya, sehingga pengetahuan yang diperolehnya semakin membaik. Semakin tua umur seseorang semakin bijaksana, semakin banyak informasi yang dijumpai dan semakin banyak hal yang dikerjakan sehingga menambah pengetahuannya. (Wahyudi, 2012).

Menurut peneliti dalam penelitian ini, umur sangat berpengaruh terhadap tingkat pengetahuan ibu hamil tentang asam folatdalam kehamilan, karena semakin tua umur seseorang, maka tingkat pengetahuan seseorang akan semakin baik. Dengan demikian dari hasil penelitian ini tidak ditemukan kesenjangan antara teori dan hasil penelitian.

\section{Hubungan Pendidikan Terhadap Pengetahuan Ibu Hamil Tentang Konsumsi Asam Folat di Klini Bersalin Keliat \\ Pendidikan merupakan salah satu faktor yang} mempengaruhi pengetahuan ibu tentang konsumsi asam folat. Berdasarkan hasil penelitian diketahui bahwa ibu hamil yang berpengetahuan kurang mayoritas adalah ibu dengan pendidikan menengah kebawah yaitu 46 orang $(79,9 \%)$ dari 58 orang yang berpengetahuan kurang, sedangkan minoritasnya adalah ibu yang berpendidikan menengah keatas yaitu 12 orang (40,0\%). 
Hasil uji Chi - Square $\left(X^{2}\right)$ diperoleh nilai $p<$ 0,$05 ; \mathrm{RP}=0,630(95 \%, \mathrm{Cl}: 0,383-1,037)$ yang artinya ibu yang memiliki pendidikan menengah kebawah akan mempunyai pengetahuan kurang 0,630 kali dibanding dengan ibu yang memiliki pendidikan menengah keatas. Sedangkan dengan melihat nilai $p$ value $(<0,05)$ maka disimpulkan bahwa terdapat hubungan yang bermakna antara pendidikan dengan pengetahuan ibu hamil tentang konsumsi asam folat.

Hal tersebut sesuai dengan teori yang dikemukanan oleh Wahyudi (2012), yang menyatakan bahwa Pengetahuan sangat erat kaitannya dengan pendidikan dimana diharapkan seseorang dengan pendidikan tinggi, maka pengetahuan orang tersebut akan semakin luas dan baik. Semakin tinggi tingkat pendidikan semakin baik pengetahuan ibu tentang konsumsi asam folat. Hal ini sesuai dengan penelitian Prasetyo (2011) mengatakan bahwa pengetahuan ibu hamil tentang konsumsi asam folat yang baik paling banyak pada pendidikan menengah, sedangkan yang memiliki pengetahuan kurang paling banyak pada pendidikan dasar. Dalam penelitian ini, tingkat pendidikan sangat berpengaruh terhadap tingkat pengetahuan ibu hamil tentang asam folatdalam kehamilan, karena semakin tinggi tingkat pendidikan ibu maka tingkat pengetahuan ibu tentang asam folat dalam kehamilan akan semakin baik. Dengan demikian dari hasil penelitian ini tidak ditemukan kesenjangan antara hasil penelitian dan teori

\section{Hubungan Sumber Informasi Terhadap Pengetahuan Ibu Hamil Tentang Konsumsi Asam Folat di Klinik Bersalin Keliat Tahun 2012}

Berdasarkan hasil penelitian diketahui bahwa ibu hamil yang berpengetahuan kurang mayoritas adalah ibu yang tidak mendapatkan Informasi tentang asam folat yaitu 46 orang $(76,7 \%)$ dari 58 orang yang berpengetahuan kurang, sedangkan minoritasnya adalah ibu yang mendapatkan informasi yaitu 12 orang $(35,3 \%)$.

Hasil uji Chi - Square $\left(X^{2}\right)$ diperoleh nilai $\mathrm{p}<$ 0,$05 ; \mathrm{RP}=2,954(95 \%, \mathrm{Cl}: 1,324-6,588)$ yang artinya ibu hamil yang tidak mendapatkan informasi mmiliki pengetahuan kurang 2,954 kali dibandingkan dengan ibu yang mendapatkan informasi. Sedangkan dengan melihat nilai $\mathrm{p}$ value $(<0,05)$ maka disimpulkan bahwa terdapat hubungan yang bermakna antara sumber informasi dengan pengetahuan ibu hamil tentang asam folat dalam kehamilan.

Informasi yang diperoleh dari berbagai sumber mempengaruhi tingkat pengetahuan seseorang. Jika seseorang banyak mendapat informasi tentang asam folat, maka tingkat pengetahuan ibu tentang konsumsi asam folat akan semakin baik (Notoatmodjo, 2007). Menurut wahyudi (2012), informasi yang didapat akan mempengaruhi tingkat pengetahuan, semakin banyak informasi yang didapatkan seseorang, maka pengetahuan seseorang itu akan semakin baik. Dalam penelitian ini, sumber informasi sangat berpengaruh terhadap tingkat pengetahuan ibu hamil tentang konsumsi asam folat karena semakin banyak ibu mendapatkan informasi tentang asam folat, maka tingkat pengetahuan ibu hamil tentang konsumsi asam folat akan semakin baik. Dengan demikin dari hasil penelitian ini tidak ditemukan kesenjangan antara hasil penelitian dan teori

\section{KESIMPULAN DAN SARAN}

\section{Simpulan}

1. $76,5 \%$ ibu hamil berpengetahuan kurang di Klinik Bersalin Keliat.

2. Terdapat hubungan yang bermakna antara umur dengan pengetahuan ibu hamil tentang konsumsi asam folat.

3. Terdapat hubungan yang bermakna antara pendidikan dengan pengetahuan ibu hamil tentang konsumsi asam folat.

4. Terdapat hubungan yang bermakna antara sumber informasi dengan pengetahuan ibu hamil tentang konsumsi asam folat.

\section{Saran}

1. Penelitian ini hanya mengkaji faktor internal ibu yang memengaruhi pengetahuan tentang asam folat dalam kehamilan. Perlu dikaji faktor lain yang memengaruhi pengetahuan ibu seperti bidan ataupun tenaga kesehatan.

2. Perlu dilakukan analisis konsumsi makanan ibu hamil untuk menilai asupan asam folat ibu setiap harinya.

3. Bidan perlu meningkatkan KIE kepada ibu hamil tentang asam folat dalam kehamilan.

\section{DARTAR PUSTAKA}

Aprillia, Yesie. 2011. Kurang Asam Folat Sebabkan Bayi Cacat. Dalam http://www.bidankita.com diakses pada tanggal 23Mmaret 2015.

Arini. 2012. Mengapa Seorang Ibu Harus Menyusui. Jogjakarta: Flashbook.

Admin. 2009. Asam Folat Mencegah Bayi Cacat. http://www.kimiafarmaapotek.com/index.php?op tion=com content\&view=article\&id=783:asamfolat-pencegah-bayicacat\&catid=222: kesehatan keluarga\&Itemid $=97$. Diakses pada tanggal 4 April 2015.

Arisman. 2010. Gizi dalam Daur Kehidupan.EGC. Jakarta. Departemen Gizi dan Kesehatan Masyarakat. 2011. Gizi dan Kesehatan Masyarakat. Jakarta: Raja Grafindo Persada.

Depkes, RI. 2006. Penyusun Karya Tulis Ilmiah. Medan : Politeknik Kesehatan Medan

Dinkes. 2010. Profil Kesehatan Indonesia Tahun 2010. www.depkes.go.id diakses pada tanggal 20 Nopember 2014.

Dyahumi. 2011. Kurang Asam Folat Saat Hamil Bisa Menyebabkan Bayi Cacat. http://artikelgizikesehatan.blogspot.com/2011/10/ kurang-asam-folat-saat-hamil-bisa.html. Diakses pada tanggal 23 Nopember 2014. 
Ellya. 2010. Gizi Dalam Kesehatan Reproduksi. Jakarta: Trans Info Media.

-------,dkk. 2010. Kesehatan Reproduksi Wanita. Jakarta: Trans Info Media.

Hunter. 2005. Makanan Yang Aman Untuk Kehamilan. Jakarta : Arcan.

Iwa. 2011. Fakta Baru Manfaat Asam Folat Terhadap NTD (Neural

Tube

Defect).http://www.kalbe.co.id/healthnews/21127/fakta-baru-manfaat-asam-folatterhadap-ntd-neural-tube-defect.html/ diakses pada tanggal 25 Maret 2015.

Lusa. 2009. Asam Folat Bagi Ibu Hamil. http://www.lusa.web.id/asam-folat-bagi-ibuhamil/ di akses pada tanggal 24 Nopember 2014.

Maman, El. 2011. Kamus Pintar Kesehatan Wanita. Yogyakarta: Buku Biru.

Misaroh, Atikah. 2010. Nutrisi Janin dan Ibu Hamil. Yogyakarta: Nuha Medika.
Notoatmodjo. 2007. Kesehatan Masyarakat Ilmu Dan Seni. Jakarta: rineka cipta.

-. 2010. Metodologi Penelitian Kesehatan. Jakarta : Rineka Cipta.

Nurhayati. 2009. 9 Bulan Yang Menakjubkan: Garamon Muchtadi. 2009. Pengantar Ilmu Gizi. Bandung. Alfabeta.

Prasetyo. 2011. Gambaran Pengetahuan Ibu Hamil Terhadap Asupan Asam Folat Pada Masa Kehamilan. http://respiratory/usu.co.id. Diakses tanggal 26 Maret 2015

Proverawati, Atikah. 2011. Anemia Dan Anemia Kehamilan. Yokyakarta: Nuha Medika.

Wahyudi, Zuli. 2012. Definisi Pengetahuan Serta Faktorfaktor Yang Mempengaruhi Pengetahuan. http://duniabaca.com/definisi-pengetahuan-sertafaktor-faktor-yang-mempengaruhi pengetahuan. html. Diakse pada tanggal 25 Nopember 2014. 